\title{
YHWH and the God of philosophical theology ${ }^{1}$
}

J W Gericke

(University of Pretoria)

Many bore witness but their testimony did not cohere

Mk 14:56

\section{ABSTRACT \\ YHWH and the God of philosophical theology}

In popular orthodox Christian philosophical theology, it is often taken for granted that the divine philosophised about is none other than the Hebrew deity YHWH himself. Moreover, it is often assumed that the Old Testament depicts YHWH as being, inter alia, single, omnipotent, omniscient, omnipresent, and eternal. Now while it is to be admitted that there are indeed depictions of YHWH in the Old Testament in which his profile might be thought of as corresponding more or less to the popular philosophical ideal, it is also true that there are many representations that contradict it. In this article, the author looks at how the popular profile of YHWH in the Old Testament as reconstructed by some philosophical theologians claiming to be 'biblical' is deconstructed when it is juxtaposed with alternative renderings of the divine in the same texts.

\section{INTRODUCTION}

Traditional orthodox Christian thinking about the nature and attributes of God operates on the dual assumption that there is only one God and that this deity is none other than YHWH as depicted in the Old Testament texts (cf. Cupitt 2002:57; Mawson 2005:22) The presumed correspondence between intra-textual and extra-textual reality is itself based on an ontological premise stating that Christian theology should not be equated with theism per se but, as long as it intends to be Christian, with biblical theism. Axiomatic therefore is the belief that only by constructing a profile of the divine rooted in the witness of the biblical texts will one be able to come up with a Christian-specific view of God (Mawson 2005:22).

1 This article was written as part of a post-doctoral fellowship in the Department of Old Testsment Studies in the Faculty of Theology at the University of Pretoria. 
Of course, popular Christian philosophical theologians' claims about the wholly biblical nature of its reconstruction of divine nature can be considered valid if, and only if, there exists a near isomorphic relationship between the representations of YHWH in the text and the onto-theological god-talk of the philosophers. However, the realisation that such may very well not be the case dawned with a vengeance after the separation of biblical and dogmatic theology late in the eighteenth century. For particularly since the historical turn in biblical scholarship, what became readily apparent was earlier philosophical theologians' (and biblical scholars'!) propensity for eisegesis ('the reading of foreign ideas into the text', as opposed to exegesis) as a result of the ideological constraints and filtering effect of dogma. In addition, historical-critical readings would reveal a subversive and deconstructive pluralism within Old Testament godtalk and numerous trajectories in its discourse that contained representations of the divine which seemed utterly alien compared to what was believed about the God of Christian onto-theology (cf. Fretheim 1984:2; Carroll 1991:26; Miles 1995:56; Wilson 1999:222; Waugh 2002:251-254).

Even so, to this day there are those Old Testament scholars who still seem to exhibit a compulsion to harmonise the differences between the pre-philosophical and ambiguous representations of the deity of ancient Israel and the systematized, domesticated and ideal representations of the God of Christian philosophical theology. These biblical theologians have as their counterparts those philosophical theologians who are themselves unable to detect any serious discrepancies between the discourse of biblical theomythology and the onto-theological jargon of the philosophy shop (to use the phraseology of William James).

An example of this latter tendency can be found in the work of Mawson (2005). According to Mawson (2005:7-63) the real God exhibits, inter alia, the following attributes: He is the only God (one); He knows everything, including the future (omniscient, precognisant); He is present everywhere (omnipresent); He can do anything (omnipotent); He is wholly good (omnibenevolent); and $\mathrm{He}$ is eternal and beyond time. Now there is nothing unorthodox or odd about insisting that such are the attributes of deity - many (arguably most) learned Christian laity and theologians throughout Church history would have agreed and have indeed implied as much (cf. Morris 1991:3). Yet Mawson and his ilk are curiously unreflective in 
that they are also under the sincere impression that such attributes of the divine represent what they call the 'biblical' view of God, a.k.a. YHWH. And by the concept of 'biblical' they do not simply mean that such attributes of the divine are attested in some of the biblical texts. Rather, the orthodox view of God is thought to represent a true reconstruction of what the entire biblical canon in all its detail allegedly has to say about the divine.

Moreover, it has not only been many philosophical theologians who have unwittingly been engaging in anachronistic philosophicaltheological reconstruction. Even many prominent Old Testament theologians of an otherwise critical disposition have at times been found generalising about the Old Testament's representations of YHWH whilst uncritically employing the philosophical-theological terminology of the omni-x type (cf. Eichrodt 1967:114-117; Von Rad 1957:44). Hence it should not come as a surprise that it is only relatively recently in the Anglo-Saxon world that a body of scholarly literature has arisen in Old Testament theology in which the philosophically-ideal descriptions of the nature of YHWH have come under severe and sustained criticism. And so it is now considered commonplace that the biblical texts cannot so easily be harmonised with popular Christian assumptions about what, given the supposed biblical roots of all Christian theology, was expected to be encountered in 'God's Word' (cf. Fretheim 1984:22-109; Barr 1984:44-56; Carroll 1997:33-51; Clines 1980:323-330; Wifall 1979:5; Tillich 1955:12; Brueggemann 1997:39).

Not that the idea or concept behind the dissonance concerning the asymmetrical relationship between some of the most cherished depictions of God and YHWH is anything new in itself. As noted above in connection with theological pluralism, already in the Old Testament itself, an intra-canonical dialectic seems to be detectable on the level of inter-textual and inter-trajectoral polemical allusions (cf. Fretheim 1984:12; Brueggemann 1997:64). The same tendency continues and intensifies subsequently as can be inferred from the blatant reinterpretations, the obvious repression and the desperate harmonisation of earlier traditions in the LXX, the Targums, the Vulgate, the Peshitta, the New Testament, in Philo, in Marcion, in Origen, in Augustine and ever since. In this sense at least - with reference to the utilisation of Old Testament god-talk as reference all modern and post-modern Christian theology may be seen as exercises in reconstructive mythology. 
Familiar as the tension between biblical and systematic theology may be to many readers, given the lack of biblical literacy, critical reflection and historical consciousness within the Church at large, another reminder of the problematic need not be considered redundant. For there exists a pervasive fundamentalism among many of the laity and clergy. And so time and time again whenever a biblical scholar tries to communicate certain aspects of the problematic to the public, there is always a backlash and an accompanying outrage. This is typically and recurrently followed by fervent and sincere calls from laity, clergy and theologians for the Church to return to the 'biblical' view of God.

Such invitations to return to what the Bible allegedly says about the divine, laudable and sincere as these may be, are immensely problematic and represent a naïve simplification of what is really involved in a very complex matter that cannot be settled by eclectic recourse to a pseudo-biblical corpus of dicta probanta. For such is a strategy of evasion, based as it is on either ignorance or repression of both the pluralism in the biblical texts and the incongruities between god-talk in biblical theology vis-à-vis dogmatic and philosophical theology (cf. Le Roux 1994:75-92; Spangenberg 1998:92; König 2002:2).

It is against the background of the communication gap between the biblical and philosophical theologians on the one hand, and the fundamentalism within the Church on the other hand, that this article hopes to make a contribution. However, the objective is not to provide final answers to perennial questions, but rather the furnishing of a prolegomena to further debate. For it is assumed that one cannot talk sensibly about answers and solutions at all if the nature, extent and scope of the problematic have not been sufficiently been grasped.

\section{UNORTHODOX REPRESENTATIONS OF YHWH IN THE OLD TESTAMENT}

With regard to outline and contents, the presentation to follow will be organised around an inversion of the alleged attributes of God as constructed in popular philosophical theology. Thus attention will be paid to those trajectories in Old Testament Yahwism that appear to be unorthodox from a popular - if stereotyped - Christian philosophical-theological perspective. Thus the focus will be on those witnesses implying that YHWH is not single, omniscient, 
omnipresent, omnipotent, eternal and transtemporal. Other alternative and equally problematic Old Testament assumptions about the divine nature, such as those implicating YHWH in the actualisation of evil, assuming that the deity is gendered and male, etc., while acknowledged, are not presently of primary concern and have been discussed elsewhere (cf. Gericke 2005a; 2005b).

Moreover, it is crucial to take cognisance of the fact that it is not my intention, with this discussion, to either endorse or degrade the heterodox trajectories in the text, or the orthodox ones, for that matter. If I could summarise, the presentation below is not aimed at telling the readers what they should believe, should not believe, or even an outline of what I myself do or do not believe - it is simply a selective reconstruction of repressed theological discourse meant to draw attention to certain types of god-talk that many people who claim to know the Bible would deny is there at all. In other words, the intention is not to be prescriptive, evaluative or normative. Rather, the objective of this discussion is simply to be informative and descriptive with the aim of creating awareness.

\subsection{YHWH was not always assumed to be the only god}

According to popular orthodoxy, the Old Testament supposedly and consistently proclaims a monotheistic faith (Kaiser 1996:12). There is only one god, YHWH, and all the other deities are mere fabrications of sinful human imagination. Prima facie, many Old Testament texts seem to share this theoretical monotheism (cf. Dt 6:4; Is 45:7; etc.; NT passim). However, in stark contrast to this view, non-fundamentalist Old Testament theologians have noted the existence of several ideas within the texts that seem to complicate the theory that Yahwism was a pure and unambiguous prototype of later philosophical monotheism. Hence many scholars of Israelite religion would consider concepts such as "monolatrism", "monoYahwism" or "henotheism" as providing a more appropriate frame of reference for the many instances where the existence of another god or other deities may actually be taken for granted in the Old Testament's discourse (cf. Eichrodt 1961:185; Cross 1962:225; Chestnut 1968:2).

Thus, in the Genesis version of the divine garden, the snake told Eve that eating from the fruit of the tree of knowledge would allow them to

...become like gods (plural), 
those who know (literally 'knowers' [plural]) (of) good and evil (Gn 3:14).

When the couple ate, YHWH told his companions that:

Now the human has become like one of us (plural) (Gn 3:22).

Later on in Genesis we read of the 'sons' of God (Gn 6:1-2), implying, perhaps, the earlier veneration of a goddess who would be their mother - contra to later reinterpretation of the 'sons' as angels (Smith 2001:132). We also find the remains of polytheistic mythological motifs in YHWH's invitation to other gods to join him in his descent to earth to confuse humanity (Gn 11:16). Then there is the account of Jacob's covenant with Laban in which the latter reminds the patriarch that the god of Abraham and the god of Nahor, they (plural in the Hebrew) will judge between them (Gn 31:53; cf. the discussion by Gerstenberger 2002:54-55).

When we come to the story of the Exodus, when YHWH was about to deliver the Israelites from Egypt, he is depicted as saying:

"...I shall go through Egypt in this night and...enact punishment over all the gods of Egypt" (Ex 12:12).

Rationalising this discourse with the claim that these 'gods' were not really thought of as actually existing or that they were really human rulers misses the point and ignores that fact that YHWH's punishment loses its magnificence if the deities are non-existent or mere mortals. Also, such reinterpretation ignores the response to the same deliverance, in which it was confessed that:

"Now I know that YHWH is greater than all the gods" (Ex 18:11).

Later on in the narrative, as part of the divine law given to the people at Sinai it was said, on the one hand, that a slave who wishes to remain with his master should be brought before the god(s) (elohim) of the doorway (cf. Ex 21:6; a reference not to YHWH according to most commentators and erroneously translated as 'authorities'; cf. Gerstenberger 2002:46). On the other, hand, YHWH himself is supposed to have warned the people with the command:

"You may not curse the gods" (Ex 22:28).

Such polytheism should not come as a surprise since many contemporary histories of Israelite religion are virtually concurrent in the belief that in pre-exilic times, Israelite society was thoroughly 
pluralistic and that the monotheism presented by the historical narratives in the canon is a retrojection from the ideological perspective of the Second Temple Period (Albertz 1992:21; Smith 2001:2; Gerstenberger 2002:45).

It would seem, however, that not only polytheistic tendencies were operative in the pre-exilic period. In fact, in some ancient traditions, the underlying theological ontology also shows traces of henotheism. Thus, according to some scholars (cf. Smith 1991:57; 2001:72; De Moor 1997:62), we find in Deuteronomy 32 an old and obscure piece of poetry (the Masoretic text is corrupt and the LXX shows a deliberate rewriting) in which YHWH actually appears as a 'son' of El.

"When Elyon gave an inheritance to the nations, when he parted the sons of humans from one another, he determined the borders of the peoples according to the number of the sons of El. But YHWH's portion is his people; Jacob is his measured out inheritance" (Dt 32:8).

The idea that YHWH could have once been thought of as a son of El, this heterodox view is implied also in the personal name of the prophet called Ahiyah [1 Ki 14]. The name actually means, 'Yah is my brother' (emphasis mine). Moreover, acknowledgment of the territorial status of gods and by implication the existence of more than one deity is also found explicitly in another seldomly preached about text:

"Thus YHWH, the god of Israel, drove away the Amorites before his people Israel, and you want to take it into possession? Will you not take into possession what your god Chemosh gave you while we take into possession that which YHWH our god drives out before us?" (Jdg 11:23-24).

One of the most well known texts indicative of the belief in more than one god (even on the part of YHWH) is, however, the familiar text of Psalm 82. This text shows not only that there used to be more than one god but that the disappearance of these deities from heaven is to be accounted for by their being condemned to death:

"God stands up in the assembly of El; He judges in the midst of the gods...I have said myself, "you are all gods, and you are all sons of the Most High"” (Ps 82:1,6). 
Note here that there is present a definite distinction between God, El (=the Most High), and the gods. Many interpreters of the Old Testament, embarrassed with this and with the reference to other deities, have reinterpreted this text to harmonise it with a monotheistic ideology by arguing that $\mathrm{YHWH}=\mathrm{El}=$ Most High and that the 'gods' are actually human rulers (as were the sons of God in Gen 6) (cf. Kaiser 1996:161). But this reinterpretation is an obvious error born of desperation. For, on the one hand, it makes nonsense of the fact that God's reference to the Most High was not a reference to himself. On the other hand, God's condemnation of human rulers would be superfluous since all mortals are destined to die by analytic a priori definition and no new divine decree is required for such to happen.

Concerning henotheism/monolatrism/mono-Yahwism, the scenario in Psalm 82 is elaborated from a different angle by the popular strand in the Old Testament Psalter according to which YHWH is worshipped as King of the gods

"... all the gods bow down before him...You are exalted over all the gods" (Ps 97:7, 9).

It would make little sense - and hardly amount to a compliment - if these 'gods' were interpreted as humans, angels or non-existent deities. And, while some traditions hailed YHWH as the number-one ranked divinity, there is another tradition that alludes to the Ugaritic myth of Athar's attempt to usurp the top-spot of El/Baal in its application of the motif to a Yahwistic context. Thus in the text of Isaiah 14 we find the remains of the polytheistic mythological motif of the fallen divinity:

"You said, 'I want to climb up to the heavens... and sit on the mountain of meeting (of the gods) in the far reaches of the north"" (Is 14:13).

In contrast to this kind of hubris among the lesser gods and their desire to rise above the heavens, the abode of deities were also found in lower spaces:

"I dwell in the dwelling of the gods (plural) in the heart of the sea" (Ezk 28:2).

They could even enjoy horticultural aesthetics:

"In Eden, the garden of the gods (plural)" (Ezk 28:13). 
But most of the time, the gods concerned themselves with politics, as even the late (monotheistic?) text of Daniel would have it:

"Thus he will act...with the help of a foreign god..." (Dn 11:39).

One could also point out that many additional possible instances of henotheism or polytheism could be added to the list of texts already presented. For example, consider the suspicious, mysterious yet not infrequent use of the plural in verbs with "Elohim" (cf. Gn 1:26; 20:13; 35:7; Ex 32:4, 8; 2 Sm 7:23; etc.).

In sum then, it is easy to "prove" that the religion of the Old Testament is strictly and uniquely monotheistic if one limits oneself to a certain selection of like-minded "proof-texts" to settle the issue or reinterprets any suspicious trajectories to harmonise them with more kosher beliefs. However, as the texts quoted above demonstrate (and there are many more where these came from), the remains of polytheistic and henotheistic mythological motifs still linger in many Old Testament texts. In such instances, the underlying ideology is, at best, one of monolatrism and many authors knew nothing of an unadulterated philosophical monotheism.

\subsection{YHWH was not always assumed to be omniscient}

Orthodox theology also conceives of God as being omniscient (cf. Kaiser et al. 1996:77). By this designation it is meant that God knows everything, past, present and future. Some Old Testament texts can even be considered as endorsing the same idea (cf. Ps 139; $\operatorname{Pr} 15: 11$; Is 41:21-24; 44:7,24-26; 45:21; 46:9,10; 48:3-8; cf. $55: 10,11)$.

Once again, however, there are other texts in which YHWH is sometimes depicted as being not quite as omniscient as post-biblical philosophical theology would consider to be the minimum requirement for a real God. In one text, for example, YHWH has to make sure that the information reported to him is indeed correct:

"Furthermore YHWH said, 'The outcry against Sodom and Gomorrah is truly great and their sin is very heavy. I want to go down in order to see whether they have actually acted according to the outcry over them which has come to me; and if not, I want to know it"" (Gn 18:17).

In another, YHWH seems unsure of what the future holds:

"When Pharaoh let the people go, God did not let them travel along the road which led to the land of the Philistines, even 
though it would have been shorter, for God said, 'What if the people become fearful when they see war and decide to go back to Egypt?"' (Ex 13:17).

Elsewhere, YHWH is depicted as having to test people to find out their inner intentions:

"Do not raise your hand against the child for now I know that you fear God...' (Gn 22:12) (emphasis mine).

"And you must think about the entire way along which YHWH your god has led you for forty years in the desert to humble you and to test you in order to know what is in your heart, whether you will listen to his commands or not" (Dt 8:2) (emphasis mine).

"... and God left him in order to test him, in order to discover everything that was in his heart" (2 Chr 32:31) (emphasis mine).

YHWH can even be represented as someone having made a mistake in his expectations of which future possibility will be actualised:

"And I thought, 'After she has done all this she will return to me'; but she did not return. ...I thought how I would set you among my sons, and give you a pleasant land...And I thought you would call me, 'my father', and would not turn from following me. Surely, as a faithless wife leaves her husband, so you have been faithless to me, O house of Israel"' $(\mathrm{Jr} 3: 7,19)$.

The plain sense of these texts featuring questions, perplexity, uncertainty and the need for information on the part of YHWH clearly implies that according to some Old Testament texts, YHWH does not know everything about either the present or the future (cf. also Fretheim 1984:45-59). All apologetic attempts to harmonise these unorthodox depictions of the deity via analogies, reinterpretation, comparative proof-texting and other types of rationalisation may once again be considered as being symptomatic of an addiction to dogma rather than the result of a genuine attempt to take the text seriously on its own terms.

In addition to what was said above regarding implicit denials that YHWH is omni-cognisant, it may be pointed out that limits to precognition are also assumed in all those instances where YHWH hardly the immutable unmoved mover of philosophical theology - is depicted as changing his mind in light of new information. The deity often repents of actualising the "evil" he had planned after a human 
mediator convinced him that the particular course of action would not be a wise move (cf. Gn 6:6, 8:21; Ex 32:10-14, Nm 22:20-22 [contra 23:19!]; 1 Sm 2:30, 15:11 [contra 15:29!]; Am 7:3,6; Jon $3: 10$, etc.). The particular modes of divine repentance as depicted in these and other Old Testament texts cannot be harmonised with the belief in divine immutability.

As Fretheim (1984:113-117) correctly observes, many Old Testament texts clearly depict a deity who had to modify his agenda as the result of something happening which he did not foresaw when he initially established particular relationships. Claiming that YHWH actually knew all along what was what and that the apparent limitations are epiphenomena of anthropomorphism makes nonsense of both the plot in the particular narrative and the integrity of the deity's character and his dialogue (Fretheim 1984:53). Moreover, the popular suggestion that YHWH did not really change his mind, it was merely the people who changed and therefore their relation to the unchanging deity was modified, causing him to change his disposition (i.e. to 'repent') also contains faulty logic. For this too represents an ad hoc rationalisation that conveniently ignores the plain sense of the texts involved.

\subsection{YHWH was not always assumed to be omnipresent}

In traditional orthodox philosophical theology it is also commonly believed that the true God is omnipresent (cf. Kolak 1994:121). Even some non-fundamentalist Old Testament scholars consider this to be the case and try to show that, despite appearances to the contrary, YHWH is indeed believed to be present, in some sense, everywhere in heaven and on earth (Fretheim 1984:60-78).

However, the belief that YHWH is always in the Old Testament depicted as being omnipresent seems once again to be based on either ignorance or repression. To be sure, there are many texts in the Old Testament suggesting that YHWH is present everywhere (cf. Ps 139; Jr 23:23-24). However, even more texts in the Old Testament, understood in their plain sense and in their immediate context, quite clearly imply the contrary. Consider the following passages, all of which depicts YHWH as a being who is not omnipresent:

YHWH walks to reach locations:

"And they heard the voice of YHWH the god while he was walking in the garden during the wind of the day. And YHWH 
the god called to the human and said to him, "Where are you?"' (Gn 3:9).

YHWH needs to travel to reach a destination, and sometimes needs to go down:

"Then YHWH went down to look at the city and the tower that the sons of man had built. And YHWH said, ...Come, let us go down and confuse their language so that the one does not understand the other..." (Gn 11:4-9).

And on other occasions he must go up:

And God left off talking with Abraham and God ascended upwards from him (Gn 17:22).

YHWH not only travels to get down to earth, even once there, people must approach YHWH or can remain far away from him:

"While YHWH descended on to the mountain Sinai, from its top YHWH called Moses to the top of the mountain and Moses climbed up. And YHWH said to Moses, 'Climb down and warn the people that they must not attempt to break through to YHWH to see..." (Ex 19:20-21).

In fact, there are definitely some spaces of which it is said that in them YHWH is not present:

"And he said, 'Go out and stand on the mountain before the face of YHWH. And look, YHWH went passed while a strong wind tore the mountains and broke the rocks from before YHWH, but in the wind YHWH was not. And after the wind there was an earthquake, but in the earthquake YHWH was not. And after the earthquake there was a fire but in the fire YHWH was not..." (1 Kgs 19:11).

Even in heaven, YHWH's servants can depart from or come into the presence of the deity so that he needs to question them about where they were - something meaningless if he was omnipresent (or omniscient, for the matter):

"And one day, when the sons of God came to set themselves before YHWH, the Satan also came among them. Then YHWH asked the Satan, 'Where did you come from?'” (Jb 1:6).

These are but a few examples of texts that would be meaningless on the assumption that YHWH is present everywhere. Popular apologetic attempts to harmonise these texts with those that do 
suggest that YHWH was considered to be omnipresent after all are all unconvincing and the analogies they use are often weak, convincing only to those whose credulity is exceded only by their will-to-believe. In addition, both with regard to the issue of divine presence and in connection with the divine attributes discussed in this article, critical scholars' appeal to the fact that the texts in question belong to different genres and historical contexts, though a correct observation, changes nothing about the assumed divine limitations implicit in the discourse.

Thus in these texts the lack of presence on YHWH's part cannot be explained away by appealing to the supposed distortive influence of genre or, for that matter, anthropomorphism, metaphor, divine accommodation, the limits of human language, or merely the failure to distinguish between omnipresence and 'intensifications of presence' (contra Fretheim 1984:35). Many of the Old Testament authors did not subscribe to such modern theological dinstinctions or philosophical standards of ideal divinity and had no problem with thinking of YHWH as an entity occupying a limited space.

\subsection{YHWH was not always assumed to be omnipotent}

Of course, if YHWH is depicted at times as being neither omniscient nor omnipresent, he is by implication at those times not omnipotent either. Yet most biblical readers never make this link and instead continue to insist both that the biblical view of God is the correct one and that omnipotence is an essential prerequisite for deityhood (cf. Kaiser et al. 1996:133).

Now according to the Old Testament in general, YHWH is indeed an extremely powerful deity. In fact, in the discourse of several texts, the idea of divine omnipotence is not far away ( $\mathrm{Gn}$ 18:14; Isa 59:1; etc.). However, a closer look at these texts shows that such rhetoric is often merely the hyperbolic objectivication of the will-to-power. Moreover, any thorough reading of the rest of the Old Testament without the constraints of dogmatic ideology will reveal that there are also many other texts where what is implied about the divine power makes the idea of omnipotence something entirely out of place:

- On the seventh day of creation, YHWH rested so as to be 'refreshed' (Ex 31:17; cf. Ex 20:11). Needing refreshment implies having being wearied and having suffered a diminishing of vital powers. 
- In the Yahwist's view, YHWH had to wait for the heat of the day to subside before taking a walk in the garden (Gn 3:8).

- YHWH is afraid of human potential and shows fear (cf. Gn $3: 22 ; 11: 5-7)$.

- There are some inevitable future destinies of peoples that even YHWH seems powerless to change (cf. Gn 15:13; 16:12; 18:17-18).

- $\quad$ YHWH needs to travel to obtain and information and confirm reports (implying that he is neither omnipresent nor omniscient and ipso facto not omnipotent; cf. Gn 3:8-11, 11:5-7, 18:7).

- YHWH cannot allow Israel to drive out the Canaanites too quickly for the fear that the wild animals might become too many (cf. Dt 7:22).

- $\quad$ YHWH did (could?) not completely destroy all forces of chaos (Leviathan, Yam) (Jb 38, 41 and OT passim).

- $\quad$ YHWH's presence with his people and his aid come to naught when they lose a battle against their enemies simply because the latter had iron chariots (cf. Jdg 1:21).

- YHWH is said to need help in some matters and to have cursed the people who did not come to his aid (cf. Jdg 5:23).

- YHWH is depicted as desperately looking around for assistance (cf. $1 \mathrm{Ki} 22$ : 20-23; Is 63:3-5).

- $\quad$ According to some traditions, the dead are beyond YHWH's sphere of control (cf. Pss 6:4-5; 88:10-12; Is 38:18-10).

Once again I remind the reader that I am not listing these examples of limitations on divine power as though I wanted to argue that such is the entire Old Testament's view on the matter. After all, many other trajectories are present in the discourse that comes as near to assuming divine omnipotence in the popular sense of the word as was possible in those pre-philosophical contexts. But a closer look at each of the texts referred to in the above statements shows that sheer suprarational omnipotence was not always thought of as one of the attributes of the God of Israel.

Moreover, it is no use to point to willed limitations of divine power because of respect for human freedom or due to the impossibility of illogical types of omnipotence (e.g. can God make a square circle?). Neither of these forms of rationalisation are 
applicable to the scenarios depicted in these passages. The all-toohuman ways in which YHWH acts in these and many other scenarios in the Old Testament suggest that, according to some biblical authors at least, there are indeed things that even YHWH cannot do. Such texts can therefore, upon closer scrutiny and without the need for dogmatic rationalisations, be understood as implying that the deity as depicted therein was not believed to be omnipotent in the sense many modern philosophical theologians define the concept.

\subsection{YHWH was not always assumed to be eternal and beyond time}

From a general, modern and orthodox perspective, the divine is a being who, amongst other things, is uncreated and has therefore existed from eternity past. The god is supposed to be the first cause of everything else (cf. Hick 1993:26). In contrast to this theopolitically correct profile of the relation between divinity and eternity, it may come as somewhat of a surprise for many (Old Testament specialists included!) to learn that such a prerequisite for godhood was almost unheard-of in the ancient world. In fact, there was a virtually universal belief that a god was a created entity in the sense of having itself emerged from the primordial chaos material that was perceived to be the only pre-existent and eternal phenomenon (cf. Armstrong 1993:2).

In most ancient Near Eastern cultures, and even in Greek philosophy (e.g. Plato) the chaos matter that constituted primal cosmic reality preceded the gods, many of whom were either born out of the cosmic womb or who were themselves secondary creations of the first gods (cf. Thrower 1980:27). In this regard, it is true that there is no theogenetic myth of YHWH's origins in the Old Testament. Even so, the belief that YHWH, like all other ancient Near Eastern creator gods, could have been formed out of the preexistent chaos matter might well have existed in ancient Israel, despite the fact that such a belief was not incorporated into later canonical scriptures.

Of course, many of the Old Testament texts may have assumed that YHWH was an eternal deity in the sense we speak of when we use the word 'eternity'. However, many of Old Testament witnesses that do speak of YHWH's relation to time and present him as existing $m^{\prime} l m /{ }^{\prime} d$ ' $l m$ simply means that the divine has existed and will exist for 'an indefinitely extended period of time' and not 
eternity as we understand it - a meaning almost foreign to the Hebrew language. Such references do not of necessity refer to an infinite past-future extension of consecutive sequences in linear progressive temporality.

Moreover, while there is no great number of texts to quote that explicitly talks about YHWH's own beginning in time, there is at least one that appears to allude (unwittingly?) to that very idea. For consider the meaning of what appears to be the remains of an implicit theo-genetic mythological motif in Isaiah 43:10:

"You are my witnesses, says YHWH, my servant whom I have chosen, so that you may know and may believe me and see that it is I - before me no god was formed and after me there will be no one" (Italics mine).

This statement is interesting for several reasons. First of all, it seems to be a polemical allusion to the ancient Near Eastern mythological motif of the primordial formation of divine beings (cf. Westermann 1969:113). Secondly, Old Testament scholars, all of which consider the idea of the formation of the divine to be a heterodox and unbiblical notion, misread the text by suggesting that it is simply an insistence that there never was a theogenesis of any deity whatsoever (cf. Westermann 1969:113). That this reading is errant can be ascertained from the fact that it fails to explain why YHWH should refer to a time 'before' him(self) and divine formation at all. For if the intention was simply to affirm monotheism, YHWH could simply have said:

"There is no other god".

But when YHWH says:

“...before me no god was formed..." (emphasis mine)

he is implying a) there was indeed a time before him, i.e. a period of time prior to when YHWH himself existed; b) divine beings are formed; and c) YHWH himself was the first and only deity who was formed. As for the latter half of the verse, its view of divine temporality is just as, if not more shocking then the first part. For here YHWH is depicted as saying that:

"...after me there will be no one" (emphasis mine).

This text seems to mean that a) there is a time 'after' YHWH; and b) when YHWH is no more, no one else will exist either. As is the case 
with the reference to the time 'before' $\mathrm{YHWH}$, the reference here is therefore once again temporal and orthodox readings fail to explain why the deity should refer to a period 'after' him at all if the claim is merely an assertion of monotheism. And should one argue that the motif of a coterminate divine life-span is alien to the Old Testament, this objection is invalid in as much as it presupposes the absence of theological pluralism on this issue and already assumes prior to reading that the Isaiah text cannot possibly mean what it seems to mean.

Strange as the ideas of divine formation and dissolution may seem to us today, this rather rare and indeed marginal belief in YHWH's theogenesis and theoterminus would be a logical inference from the ancient Near Eastern belief in pre-existent chaos matter (a notion also evident in Gn 1:2; and in the theo-machic creation motifs in Pss 74:13-17; 89:10-14; Jb 26:12; etc.). For in ancient Near Eastern myth, the creator of the cosmic order was generally not considered to have existed forever but was merely the first being to have come into existence from the womb of chaos.

Once one allows for at least the theoretical possibility that unorthodox ideas like these may be present in the Old Testament, several remains of other unorthodox mythological motifs regarding divine temporality vs. eternity also become apparent on the margins of the biblical traditions.

For example, consider the mythological motif of the "Tree of Life" in the garden of the gods (cf. Gn 2-3; Ezk 28). Why was there such a tree at all, even before Adam came onto the scene? Did YHWH (and his companions) have to eat from it to perpetually promote his (their) own continued vitality? Is that why he (they) was (were) so afraid when the humans ate from the tree of knowledge and they became 'like one of us' that he therefore decided to prevent them from eating from the Tree of Life so that they would not also become completely divine (cf. Gn 3:16-22)? If it was not meant for YHWH, why did he keep it sealed off but extant even after Adam was barred from access to it. Is it not because, as the text of Ezekiel 28 shows, the Tree of Life was part of what was believed to be the garden of deities?:

"In Eden, the garden of the gods (plural)" (Ezk 28:13).

And what about the most obvious function of non-expiatory types of sacrifice? For there are many types of sacrifice that are not 
consumed as meals afterwards by those who sacrificed nor did they have the function of expiating guilt and sin (e.g. burnt offerings). Thus many biblical scholars indeed believe that whatever became the case later on, and notwithstanding the many polemical denials of the belief elsewhere in the Old Testament, in earlier times some of the offerings were indeed thought of as providing sustenance and nourishment for YHWH (cf. Eichrodt 1961:142). The famliar cultic claim that all the fat belonged to YHWH was neither an allusion to divine obesity (something not uncommon in the ancient world) nor a extra-terrestrial garbage disposal for health conscious Israelites during a certain stage in pre-exilic Yahwism it was considered to be appropriate and fitting divine nourishment (cf. Lv 3:16b).

This notion would also explain why YHWH was depicted in some texts as a deity who delights in the sensual pleasure of smelling the flavour of the sacrifice (cf. Gn 8:21; Lv 1:9,13,17; 26:31 and passim) (cf. De Vaux 1978:448). It is also only on the assumption that YHWH was once believed to join in meals that one is able to account for the fact that the altar was literally called 'God's table' and the shrewbread was known as 'God's bread' (and had to be renewed at regular intervals) (Lv 21:6, 8, 17; 22:25; Ezk 44:7; Ml 1:7). The technical terminology encountered here are known from many other ancient Near Eastern texts and it would seem that, despite later polemics against it, also in early Israel was it assumed that the divine absorbed the life-giving essence of the food even when not literally eating it (cf. Eichrodt 1961:142).

De Vaux (1978:448) also notes, in this regard, the fact that sacrifices to YHWH that were not consumed by human participants were nonetheless still prepared exactly as meals and that this practice seems to confirm the view that in early Yahwism many worshippers took it for granted that YHWH partook in such delicacies and was nourished thereby. Moreover, the idea that even in heaven the intake of food is vital for sustaining and perpetuating life can be found in a text suggesting that the manna that fell in the desert was itself nothing other than the ambrosia of the gods (cf. Ps 78:25). This notwithstanding the likelihood that such references, especially those to divine dining in cultic contexts, later came to be seen as euphemisms for divine approval and metaphors of divine presence (Teeple 1982:124). 
Moreover, the idea implied here, i.e. that of the possibility of the diminishment of divine vitality and power, is itself not as alien to the Old Testament witnesses as first considerations might suggest. Thus in Genesis 2:3 we read that God 'rested' on the seventh day, whilst Exodus 31:17 explicitly insists that this was so that he may be 'refreshed'. Also, in the depiction of YHWH in Judges 10:16 it is said, that because of the people's sins and complaints, 'his (YHWH's) nephesh was shortened'. According to Fretheim (1984:129), this text can only mean that YHWH's life was somehow being expended since the image of the nepesh being shortened is found elsewhere in the Old Testament only in the context of death and the dimishment of life (cf. Fretheim 1984:113). The phrase has nothing to do with alleged impatience on the part of YHWH as virtually all translations would prefer it to be.

Of course, the depiction of YHWH as an aged deity with white hair in Daniel 7:9-14 can also be interpreted as implying the rather peculiar (if not unsettling) assumption on the part of the author that the deity can and has aged and therefore is subject to the loss of vitality that accompanies this process (cf. Davies 1995:82). The idea of an ageing deity is, however, quite familiar to the ancient Near East and some commentators have suggested that the Daniel texts depicts a god who, like the gods of Egypt and elsewhere, was not only born but also grows old and eventually dies (cf. Davies 1995:82-91). The "Ancient of Days" with his white hair sitting in a wheeled chair (a wheelchair?; cf. 7:9), YHWH certainly seems to resemble a very old monarch and a god much older than the childlike experimenter in Genesis 2.

The very idea that a god can die may seem strange to modern people but for the ancients it was quite commonplace (Tiamat, Re, Osiris, Tammuz, Baal) and features even in the Old Testament. The prophet Habbakuk may have been responding polemically to a similar belief about YHWH when he half-desperately tells YHWH that he 'will not die' (cf. Hb 1:12). The Masoretes were so embarrassed at what this text seems to imply as being possible - for the prophet does not say that YHWH cannot die - that the text was emended to 'we will not die'. It is, however, as was argued above, in Psalm 82 where one finds one familiar text that speaks of the possibility of death for divine beings. 
The idea of divine transience also has certain implications concerning YHWH's relation to time. As Fretheim (1984:56-58) notes, most Old Testament texts seem to imply that, contrary to the God of philosophical theology who is said to be beyond time, YHWH is actually bound to temporality and takes time to think and to act (cf. Gn 1-11; 15; 18; 1 Ki 22; Job 1-2; Eccl. 3:9-15; etc.). YHWH is therefore sometimes depicted as needing time to make up his mind and to give vent to his emotions and is thus neither 'beyond' time nor does he exist in a timeless present (cf. Ex 32:1014). This being the case, such seemingly 'unorthodox' or crude notions about the Hebrew deity in relation to time cannot be softened by the popular apologetic recourse to anthropomorphism or the limits of language - for to do so in the context of Old Testament theology (as opposed to dogmatic theology) would be anachronistic and eisegetical. The embarrassment at a temporally bound divinity is an occupational hazard of post-biblical philosophical theology and was unknown to many of the biblical authors themselves.

In sum then, though the idea of temporal limitations on the part of YHWH exist only scattered on the margins of the Old Testament texts in the remains of mythological motifs and subtle allusions to other Near Eastern discourses, their presence cannot be denied. Harmonisation with the more orthodox trajectories is not necessary once one accepts the reality of theological pluralism in the text and the alien nature of the culture of those people who knew nothing of modern philosophical-theological criteria for orthodoxy.

\section{CONCLUSION}

This article has demonstrated that there are definite strands in the Old Testament discourse about YHWH that are at odds with what is popularly held to be the 'orthodox', 'biblical' and even 'Christian' view of certain attributes of God. The God of Abraham, Isaac and Jacob was at times depicted as anything but single, omniscient, omnipresent, omnipotent and eternal/transtemporal.

Although there are texts in the Old Testament that people could refer to with which to argue that YHWH and the God of stereotypical Christian philosophical theology are similarly depicted with the same essential divine attributes, the belief that such a view represents the Old Testament discourse in all its diverse detail appears to be based on ignorance or repression. It occurs typically 
when Christian philosophical theology brackets the last two centuries of biblical theology.

For as many biblical scholars know, if they know anything, given the theological pluralism encountered within the Old Testament canon, it is meaningless to speak of the biblical view of God, as though the texts contained a coherent and unified witness to what was alleged to be extra-textual divine reality. Biblical theology has demonstrated, if anything at all, the substantial incommensurability prevalent in certain Old Testament trajectories between - to use Blaise Pascal's phraseology in another (almost opposite) sense and context - the God of Abraham, Isaac and Jacob and the God of the Philosophers.

\section{Consulted literature}

Albertz, R 1994. A History of Israelite Religion in the Old Testament Period (2 vols). London: SCM Press.

Anderson, B W 1962. s.v. "God", in International Dictionary of the Bible II, 417-430.

Archer, G 1982. Encyclopaedia of Bible Difficulties. Grand Rapids: Baker Books.

Armstrong, K 1993. A History of God. Oxford: Oxford University Press.

Barr, J 1984. Escaping from Fundamentalism. London: SCM Press.

Brueggemann, W 1997. Theology of the Old Testament. Minneapolis: Fortress Press.

Carroll, R P 1997. Wolf in the Sheepfold: The Bible as Problem for Christianity. London: SCM Press.

Chestnut, J S 1968. The Old Testament Understanding of God. Philadelphia: Westminster Press.

Clines, D J A 1980. YHWH and the God of Christian Theology. Theology 83, 323-330.

-, 1995. Interested Parties: The ideology of Readers and Writers of the Hebrew Bible. Sheffield: Sheffield Academic Press.

Cross, F M 1962. YHWH and the God of the Patriarchs. Harvard Theological Review 55, 225-259.

Cupitt, D 1989. Radicals and the Future of the Church. London: SCM Press.

-, 2002. Is Nothing Sacred? Essays in Non-Realist Philosophy of Religion. Cambridge: Cambridge University Press.

Davies, P R 1995. Whose Bible Is It Anyway? JSOTSup Series 204. Sheffield: Sheffield Press. 
De Moor, J C 1997. The rise of Yahwism: the roots of Israelite monotheism. Leuven: Peeters Uitgeverij.

De Vaux, R 1978. Ancient Israel. Its Life and Institutions. London: Darton, Longman \& Todd.

Eichrodt, W 1961. Theology of the Old Testament (vol 1). OTL. Philadelphia: Westminster Press.

-, 1967. Theology of the Old Testament (vol 2). OTL. Philadelphia: Westminster Press.

Fretheim, T E 1984. The Suffering of God: An Old Testament Perspective. OBT 14. Philadelphia: Fortress Press.

Geisler, N 1988. Philosophy of Religion. (2 $2^{\text {nd }}$ ed.) Grand Rapids. WB Eerdmans.

Gericke, J W 2005a. Beyond reconciliation - monistic Yahwism and the Problem of Evil in philosophy of religion. Verbum et Ecclesia 26(1) 2005, 64-92.

-, 2005b. Yahwism and projection - a comprehensive a theological perspective. Scriptura (forthcoming 2006).

Haley, J W 1992. Alleged Discrepancies of the Bible. Grand Rapids: Baker Books House.

Harwood, W 1992. Mythology's Last Gods: Yahweh and Jesus. New York: Prometheus Press.

Hick, J 1993. The Philosophy of Religion (4 ${ }^{\text {rd }}$ edition). London: Macmillan.

Kaiser, W C 1996. Hard Sayings in the Old Testament. Grand Rapids: W B Eerdmans.

Kolak, D 1994. In Search of God. San Francisco: Cosmic Press.

König, A 2002. Ek glo die Bybel. Pretoria: Lux Verbi.

Le Roux, J H 1994. God se brug na die mens: iets goddeliks of iets mensliks? Skrif en Kerk 15(1) 1994, 27-51.

Levenson, J D 1988. Creation and the Persistence of Evil. The Jewish Drama of Divine Omnipotence. San Francisco: Harper and Row.

Mawson, T J 2005. Belief in God. An Introduction to Philosophy of Religion. London: Oxford University Press.

Miles, J 1995. God: A Biography. New York: Vintage.

Morris, T V 1991. Our idea of God. An introduction to philosophical theology. Downers Grove: Intervarsity Press.

Pailin, D 1986. Groundwork of Philosophy of Religion. London: Epworth Press.

Smith, M 1991. The early history of God. Yahweh and other deities in ancient 
Israel. San Francisco: Harper \& Row.

Spangenberg, I J J 1998. Perspektiewe op die Bybel. Pretoria: Van Schaik.

Tarnas, R 1991. The Passion of the Western Mind: Understanding the Ideas that Shaped Our World-View. New York: Crown Publishers.

Teeple, H M 1992. The Historical Approach to the Bible. San Francisco: Religion and Humanism Foundations Press.

Thrower, J 1980. The Alternative Tradition: Religion and the Rejection of Religion in the Ancient World. The Hage: Mouton Publishers.

Tillich, P 1955. Biblical Religion and the Search for Ultimate Reality. Nisbet: SPCK.

Van der Toorn, K 1999. s.v. "God (1)”, in DDD, 122-132.

Van der Toorn, K (ed). 1999. Dictionary of Deities and Demons in the Bible $(D D D)$. Philadelphia: Fortress Press.

Vawter, B 1982. The God of the Hebrew Scriptures. Biblical Theology Bulletin $12,3-7$.

Von Rad, G 1957. Theology of the Old Testament (vol 1; Eng Tr, 2nd ed). London: SCM Press.

Westermann, C 1969. Isaiah 40-66: A Commentary. OTL. Philadelphia: Westminster Press.

Wifall, W 1979. Models of God in the Old Testament. Biblical Theology Bulletin 9, 179-186.

Waugh, A 2002. God. London: Headline Books.

Wilson, A N 1999. God's Funeral. London: Abacus. 